\title{
Genetic Polymorphisms of Vitamin D Receptor Gene are Associated with Cervical Cancer Risk in Northeastern Thailand
}

\author{
Sophida Phuthong ${ }^{1}$, Wannapa Settheetham-Ishida ${ }^{1 *}$, Sitakan Natphopsuk ${ }^{2}$, \\ Takafumi Ishida ${ }^{3}$
}

\begin{abstract}
Objective: This study aimed to explore whether VDR polymorphisms (Fok1, Apal and Taq1) are associated to the cervical cancer in Thai population. Materials and methods: Subjects of 204 cervical cancer patient and 204 age-matched healthy control were enrolled in the case-control study. $V D R$ polymorphisms were detected by using realtime PCR. Haplotype analysis of three loci was applied to the obtained genotypes. Results: Significantly increased risk for cervical cancer was observed in carriers of TT genotype $(\mathrm{p}=0.0388)$ and T allele $(\mathrm{p}=0.0357)$ of Fok1 and TC genotype $(\mathrm{p}=0.0001), \mathrm{CC}$ genotype $(\mathrm{p}=0.0160)$ and the $\mathrm{C}$ allele of Taq1 $(\mathrm{p}=0.0001)$. Haplotype analyses revealed a significant correlation between C-T-C, T-G-C and T-T-C haplotypes and elevated risk for cervical cancer $(\mathrm{OR}=2.06$; $95 \% \mathrm{CI}=1.06-4.00 ; \mathrm{p}=0.0313, \mathrm{OR}=2.15 ; 95 \% \mathrm{CI}=1.22-3.80 ; \mathrm{p}=0.0078$ and $\mathrm{OR}=2.81 ; 95 \% \mathrm{CI}=1.53-5.16 ; \mathrm{p}=$ 0.0006, respectively). Furthermore, haplotype carrying C allele of Taql (C-G-C + C-T-C + T-G-C + T-T-C) significantly increased cervical cancer risk with $\mathrm{OR}$ of $1.92(95 \% \mathrm{CI}=1.32-2.79, \mathrm{p}=0.0006)$. Conclusion: Our finding revealed an association between $V D R$ polymorphisms and cervical cancer risk. Taql C allele might be a molecular marker for cervical cancer development.
\end{abstract}

Keywords: Genetic polymorphism- Vitamin D receptor- cervical cancer

Asian Pac J Cancer Prev, 21 (10), 2935-2939

\section{Introduction}

Cervical cancer is currently one of the most common cancers in women worldwide (Bray et al., 2018). The underlying causes for cervical cancer are human papillomavirus (HPV) infection, genetic variation and environmental factors (Natphopsuk et al., 2012; Wang et al., 2010). In addition, there is several lines of evidence suggesting the role of calcitriol (1,25-dihydroxyvitamin D3), active form of vitamin $\mathrm{D}$, in female reproductive diseases including cervical cancer (Deuster et al., 2017; Reis et al., 2017; Vahedpoor et al., 2017). Vitamin D deficiency has been found to be associated with an increased risk of cancer (Tworoger et al., 2007).

Calcitriol, the biologically most potent form of vitamin D, exerts an antioncogenic effect, which mediates through various mechanisms; inhibition of proliferation, promotion of cell differentiation and apoptosis (Dou et al., 2016; Samuel and Sitrin, 2008). Calcitriol activity is controlled by binding of calcitriol to vitamin $\mathrm{D}$ receptor (VDR) which is then translocated into the nucleus, where it forms a calcitriol-VDR/retinoid X receptor (RXR) complex. Consequently, this complex binds to vitamin
D response elements (VDREs) on the target genes which then regulates the transcription (Pike and Meyer, 2012). In view of this control mechanism, calcitriol action thus depends on VDR activity (Uitterlinden et al., 2004).

The VDR protein is encoded by the VDR gene which is found in chromosome $12 \mathrm{q} 13.11$. This gene is expressed in normal and cancerous cervix, indicating the anti-tumor effects of calcitriol on the cervix (Deuster et al., 2017; Kaabachi et al., 2014; Reichrath et al., 1998). However, VDR activity may be influenced by VDR genetic polymorphisms (Köstner et al., 2009), several of which have been identified. The frequently studied VDR polymorphisms such as Fok1, Apal and Taq1, all involving transitions $(\mathrm{C}>\mathrm{T}$ in exon 2$),(\mathrm{G}>\mathrm{T}$ in intron 8) and ( $\mathrm{T}>\mathrm{C}$ in exon 9), respectively (Köstner et al. 2009; McCullough et al. 2007; Wang et al. 2013). Fok1 produces an alternative transcription initiation site in which the $\mathrm{T}$ allele generates the VDR protein with three amino acid longer (427 amino acids) than the protein produced by $\mathrm{C}$ allele (424 amino acids). The longer protein exerts less transactivation capacity (Amadori et al., 2017). The Apal and Taq1 polymorphic sites are close to the 3' untranslated region (3'-UTR) of $V D R$ mRNA which affects mRNA 
stability and the post-transcriptional process (Guo et al., 2018; Whitfield et al., 2001). Interestingly, Fokl have been shown to be linked with each other of 3'UTR indicating their interaction effects in modulating VDR activity (Israni et al., 2009; Kaabachi et al., 2014). As a result, most of studies have performed not only $V D R$ genotype but also haplotype analysis in relation to cancer susceptibility but the results were inconsistent (Flügge et al., 2007; Kaabachi et al., 2014; Onen et al., 2008).

The study of $V D R$ genetic polymorphisms is one approach to understand interindividual susceptibility to cervical cancer which have not been evaluated previously. Hence, this study provides the first report regarding the analysis of VDR polymorphisms (Fokl, Apal and Taq1) individually and $V D R$ haplotype on cervical cancer risk among Thai population.

\section{Materials and Methods}

\section{Study subjects}

The female volunteers were recruited from Srinagarind hospital, Khon Kaen University and Khon Kaen hospital, Khon Kaen, Thailand. Participants were divided into two groups that included 204 patients with pathologically diagnosed squamous cell carcinoma of the cervix (SCCA) and 204 age-matched healthy controls (5-years interval). Informed consent was obtained from all participants after which peripheral blood leukocytes were collected for VDR polymorphism analysis. The study was approved by the Ethic Committee of Khon Kaen university (Reference No. HE621103).
Detection of VDR polymorphisms

Genomic DNA (gDNA) was extracted from buffy coat using GF-1 Blood DNA Extraction Kit (Vivantis, USA). Real-time PCR with Taqman ${ }^{\circledR}$ probe (Applied Biosystems, USA) was used for Fokl (rs2228570), Apal (rs7975232) and Taq1 (rs731236) detection.

The real-time PCR conditions involved: a holding stage at $95^{\circ} \mathrm{C}$ for 10 minutes, followed by 40 cycles each of denaturation at $95^{\circ} \mathrm{C}$ for 15 seconds, annealing and extension at $60^{\circ} \mathrm{C}$ for 60 seconds.

\section{Statistical analyses}

Statistical analyses were performed using the STATA software. Deviation from Hardy-Weinberg equilibrium (HWE) for the genotype of each loci was tested with the Pearson's chi-square ( $\chi 2$ test). The haplotypes were inferred using PHASE algorithm version 2.1.1. Association between genotypes or haplotypes of $V D R$ and cervical cancer risk was tested by calculating the odd ratios with (OR) $95 \%$ confidence intervals $(95 \% \mathrm{CI})$ using logistic regression analyses. A two-tailed p-value of less than 0.05 was considered to be statistically significant.

\section{Results}

Table 1 presents association between $V D R$ gene polymorphisms and cervical cancer risk. Genotype distribution of VDR (Fok1, Apal and Taq1) polymorphisms among controls were consistent with HWE ( $\mathrm{p}>0.05)$. For the Fok1 and Taq1, allele frequencies were found to differ significantly between the patients and the controls

Table 1. Association between VDR Polymorphisms and Risk for Cervical Cancer

\begin{tabular}{|c|c|c|c|c|}
\hline Genotypes/Alleles & Control n (\%) & Case n $(\%)$ & Crude OR $[95 \% \mathrm{CI}, p]$ & Adjusted $\mathrm{OR}^{\mathrm{b}}[95 \% \mathrm{CI}, p]$ \\
\hline \multicolumn{5}{|l|}{ Fok $1^{a}$} \\
\hline $\mathrm{CC}$ & $55(29.6)$ & $45(22.06)$ & 1 & 1 \\
\hline $\mathrm{CT}$ & $106(51.96)$ & $96(47.06)$ & $1.11[0.67-1.84,0.6790]$ & $1.44[0.71-2.94,0.313]$ \\
\hline $\mathrm{TT}$ & $43(21.08)$ & $63(30.88)$ & $1.79\left[1.03-3.11,0.0388^{*}\right]$ & $2.66\left[1.17-6.04,0.020^{*}\right]$ \\
\hline $\mathrm{CT}+\mathrm{TT}$ & $149(73.04)$ & $159(77.94)$ & $1.3[0.81-2.11,0.2498]$ & $1.77[0.90-3.46,0.096]$ \\
\hline $\mathrm{C}$ & 0.53 & 0.46 & 1 & 1 \\
\hline $\mathrm{T}$ & 0.47 & 0.54 & $1.34\left[1.02-1.77,0.0357^{*}\right]$ & NA \\
\hline \multicolumn{5}{|l|}{ Apal ${ }^{a}$} \\
\hline GG & $100(49.02)$ & $94(46.08)$ & 1 & 1 \\
\hline GT & $83(40.69)$ & $82(40.2)$ & $1.05[0.68-1.63,0.8143]$ & $1.11[0.61-2.04,0.728]$ \\
\hline TT & $21(10.29)$ & $28(13.73)$ & $1.42[0.72-2.82,0.2771]$ & $1.96[0.79-4.84,0.144]$ \\
\hline $\mathrm{GT}+\mathrm{TT}$ & $104(50.98)$ & $110(53.92)$ & $1.13[0.75-1.69,0.5520]$ & $1.27[0.72-2.24,0.410]$ \\
\hline G & 0.69 & 0.66 & 1 & 1 \\
\hline $\mathrm{T}$ & 0.31 & 0.34 & $1.16[0.86-1.55,0.3302]$ & NA \\
\hline \multicolumn{5}{|l|}{$\operatorname{Taq} 1^{a}$} \\
\hline $\mathrm{TT}$ & $133(65.2)$ & $88(43.14)$ & 1 & 1 \\
\hline $\mathrm{TC}$ & $58(28.43)$ & $95(46.57)$ & $2.48[1.59-3.87,0.0001 *]$ & $2.36\left[1.28-4.35,0.006^{*}\right]$ \\
\hline $\mathrm{CC}$ & $13(6.37)$ & $21(10.29)$ & $2.44\left[1.10-5.58,0.0160^{*}\right]$ & $2.11[0.73-6.10,0.167]$ \\
\hline $\mathrm{TC}+\mathrm{CC}$ & $71(34.8)$ & $116(56.86)$ & $2.47[1.62-3.76,0.0001 *]$ & $2.31[1.30-4.11,0.004 *]$ \\
\hline $\mathrm{T}$ & 0.79 & 0.66 & 1 & 1 \\
\hline $\mathrm{C}$ & 0.21 & 0.34 & $1.95[1.42-2.67,0.0001 *]$ & NA \\
\hline
\end{tabular}

OR, odds ratio, CI: confidence interval, ${ }^{*} p<0.05$, NA: not applicable; ${ }^{\text {a }}$ no deviation from Hardy-Weinberg equilibrium $(p>0.05$ by $\chi 2$ test); ${ }^{\mathrm{b}}$ adjusted multiple logistic regression for partners' smoking, contraceptive use and HPV infection 
Table 2. Association between VDR Haplotypes (Fok1-Apa1-Taq1) and Risk for Cervical Cancer

\begin{tabular}{lcccc}
\hline Fok1-Apa1-Taq1 & Control n $(\%)$ & Case $\mathrm{n}(\%)$ & OR [95\%CI, p] & OR [95\%CI, p] \\
\hline C-G-T & $127(31.13)$ & $108(26.47)$ & 1 & 1 \\
C-G-C & $27(6.62)$ & $24(5.88)$ & $1.05[0.57-1.92,0.9334]$ & $1.05[0.57-1.92,0.9334]$ \\
C-T-T & $46(11.27)$ & $25(6.13)$ & $0.64[0.37-1.11,0.1094]$ & 1 \\
C-T-C & $16(3.92)$ & $28(6.86)$ & $2.06[1.06-4.00,0.0313 *]$ & $3.22\left[1.47-7.05,0.0030^{*}\right]$ \\
T-G-T & $106(25.98)$ & $97(23.77)$ & $1.08[0.74-1.57,0.7026]$ & 1 \\
T-G-C & $23(5.64)$ & $42(10.29)$ & $2.15\left[1.22-3.80,0.0078^{*}\right]$ & $2\left[1.12-3.56,0.0181^{*}\right]$ \\
T-T-T & $45(11.03)$ & $41(10.05)$ & $1.07[0.65-1.76,0.7847]$ & 1 \\
T-T-C & $18(4.41)$ & $43(10.54)$ & $2.81\left[1.53-5.16,0.0006^{*}\right]$ & $2.62\left[1.31-5.25,0.0059^{*}\right]$ \\
C-G-T & $127(31.13)$ & $108(26.47)$ & 1 & 1 \\
C-G-C + C-T-C + T-G-C + T-T-C & $84(20.59)$ & $137(33.57)$ & $1.92\left[1.32-2.79,0.0006^{*}\right]$ & $1.92\left[1.32-2.79,0.0006^{*}\right]$ \\
\hline OR, odds ratio CI, confdid
\end{tabular}

OR, odds ratio; CI, confidence interval; $* p<0.05$

$(\mathrm{p}<0.05)$

Interestingly, the TT genotype and the T allele of Fokl was significantly associated with increased risk for cervical cancer (crude $\mathrm{OR}=1.79 ; 95 \% \mathrm{CI}=1.03-3.11$; $\mathrm{p}=0.0388$ and adjusted $\mathrm{OR}=2.66 ; 95 \% \mathrm{CI}=1.17-6.04$; $\mathrm{p}=0.020$ for TT vs. $\mathrm{CC}$ and $\mathrm{OR}=1.34 ; 95 \% \mathrm{CI}=1.02-$ $1.77 ; \mathrm{p}=0.0357$ for T vs. C). For Taq1 locus, TC and CC genotypes and the $\mathrm{C}$ allele significantly increased cervical cancer risk (crude $\mathrm{OR}=2.48 ; 95 \% \mathrm{CI}=1.59-3.87$; $\mathrm{p}<$ 0.0001 and adjusted $\mathrm{OR}=2.36 ; 95 \% \mathrm{CI}=1.28-4.35 ; \mathrm{p}$ $=0.006$ for TC vs. TT and crude $\mathrm{OR}=2.44 ; 95 \% \mathrm{CI}=$ $1.10-5.58 ; \mathrm{p}=0.0160$ and adjusted $\mathrm{OR}=2.11 ; 95 \% \mathrm{CI}=$ $0.73-6.10 ; \mathrm{p}=0.167$ for $\mathrm{CC}$ vs. TT and $\mathrm{OR}=1.95 ; 95 \% \mathrm{CI}$ $=1.42-2.67 ; \mathrm{p}<0.0001$ for $\mathrm{C}$ vs. T), whereas Apal was not associated with cervical cancer risk $(\mathrm{p}>0.05)$.

Haplotype (Fok1-Apal-Taq1) analysis regarding cervical cancer risk is presented in Table 2 where C-G-T was found to be the most common in both patients and controls. C-T-C, T-G-C and T-T-C haplotypes significantly increased the risk for cervical cancer compared to $\mathrm{C}-\mathrm{G}-\mathrm{T}$ haplotype with $\mathrm{OR}=2.06 ; 95 \% \mathrm{CI}=1.06-4.00 ; \mathrm{p}=$ $0.0313, \mathrm{OR}=2.15 ; 95 \% \mathrm{CI}=1.22-3.80 ; \mathrm{p}=0.0078$ and $\mathrm{OR}=2.81 ; 95 \% \mathrm{CI}=1.53-5.16 ; \mathrm{p}=0.0006$, respectively. Interestingly, an elevated risk for cervical cancer was observed among haplotypes carrying $\mathrm{C}$ allele compared to T allele of Taq 1; C-G-C vs. C-G-T (OR $=1.05 ; 95 \% \mathrm{CI}$ $=0.57-1.92 ; \mathrm{p}=0.9334), \mathrm{C}-\mathrm{T}-\mathrm{C}$ vs. C-T-T $(\mathrm{OR}=3.22$; $95 \% \mathrm{CI}=1.47-7.05 ; \mathrm{p}=0.0030), \mathrm{T}-\mathrm{G}-\mathrm{C}$ vs. T-G-T $(\mathrm{OR}$ $=2.00 ; 95 \% \mathrm{CI}=1.12-3.56 ; \mathrm{p}=0.0181$ and $\mathrm{T}-\mathrm{T}-\mathrm{C}$ vs. $\mathrm{T}-\mathrm{T}-\mathrm{T}(\mathrm{OR}=2.62 ; 95 \% \mathrm{CI}=1.31-5.25 ; \mathrm{p}=0.0059)$. Furthermore, carriers of Taq1 C haplotype (C-G-C + $\mathrm{C}-\mathrm{T}-\mathrm{C}+\mathrm{T}-\mathrm{G}-\mathrm{C}+\mathrm{T}-\mathrm{T}-\mathrm{C}$ ) had 1.92 times higher risk for cervical cancer compared to $\mathrm{C}-\mathrm{G}-\mathrm{T}$ haplotype $(95 \% \mathrm{CI}=$ $1.32-2.79, \mathrm{p}=0.0006)$.

\section{Discussion}

To our knowledge, this study is the first to report an association between $V D R$ polymorphisms and cervical cancer risk in a Thai population. Increased risks for cervical cancer observed among carriers of the TT genotype and the T allele of Fokl polymorphism indicated this allele to be a susceptible risk allele. In agreement with these findings, the presence of the Fok1 T allele was a risk allele for ovarian, breast and renal cancers (Arjumand et al., 2012; Liu et al., 2013; Wang et al., 2013). The Fok1 T allele could decrease $V D R$ transcription and translation efficacy which was reported to reduce anti-carcinogenic properties of calcitriol and contributes to an increased cancer susceptibility (Amadori et al., 2017; Chen et al., 2018; Feldman et al., 2014). Hence, this report confirms the role of Fok1 T allele in raising cancer susceptibility.

Our finding of an absence of correlation between Apal polymorphism and cervical cancer risk agrees with reports of other studies in prostate, breast and ovarian cancers (Clendenen et al., 2008; Wang et al., 2016). The Apal polymorphism found in the intron 8 does not change the VDR amino acid sequence (Köstner et al. 2009). Therefore, Apal would be less expected to mimic VDR expression and function as seen in earlier study which provided evidence that this polymorphism does not affect VDR expression level (Selvaraj et al., 2009).

Regarding Taq1 polymorphism, our results indicate a significant role of the $\mathrm{C}$ allele in the cervical cancer risk which was not previously observed in other cancers such as breast, prostate, and colorectal cancer (Bodiwala et al., 2004; Flügge et al., 2007; Gapska et al., 2009). A variant allele of Taq1 locus has been shown to regulate VDR mRNA stability which alters expression and transactivation capacity (McCullough et al., 2009; Whitfield et al., 2001). This mechanism might alter the state of VDR in the cancer susceptibility (Chen et al., 2018; Serrano et al., 2016). To our knowledge, the C allele of Taq1 might be a potential diagnostic biomarker for cervical cancer susceptibility. Nevertheless, these conflicting results provide a hypothesis that the influence of VDR on cancer susceptibility might depend on dietary and environmental factors that potentially influence calcitriol levels and VDR activity (Bodiwala et al., 2004; Köstner et al., 2009; McCullough et al., 2007). Hence, further studies should consider gene-environment interaction to clarify the role of calcitriol and $V D R$ on cervical cancer susceptibility.

VDR haplotype (Fok1-Apal-Taq1) analysis was performed to provide more conclusive information regarding genetic variation. In accordance with allele frequencies, C-G-T haplotype was predominant in the healthy Thai population as previously reported for another 
Asian population (Li et al., 2018).

Haplotypes containing the T allele of Fokl or C allele of Taq1 (C-T-C, T-G-C or T-T-C) were associated with statistically increased cervical cancer risks compared to the most common C-G-T haplotype. Nevertheless, haplotypes carrying only Fok1 T allele (T-T-C and T-T-T) were not correlated with increased cervical cancer risk, suggesting that the effect of Fokl polymorphism might be depending on the interaction with Taq1 loci. To clarify the possible significance of Taq1 in cervical cancer risk, Taq 1 pair haplotypes analysis was performed. The presence of Taq1 C allele was found to be strongly associated with an increased risk for cervical cancer, which was in line with the result of Taq1 allelic analysis. Moreover, an increased cervical cancer risk observed in the haplotype analysis was higher than the risk observed in each allele. Thus, the role of $V D R$ genetic variation on cervical cancer susceptibility is most likely influenced by the presence of the $\mathrm{C}$ allele of Taq1 which produced less VDR activity and less responsive to calcitriol.

In conclusion, this study is the first to demonstrate the role of $V D R$ polymorphisms, especially Taq1 polymorphism in cervical cancer risk among Northeastern Thai women. Thus, the Taql C allele might be considered an important molecular marker for cervical cancer risk that may predict possible cervical cancer development.

\section{Acknowledgements}

The authors thank all the staff and patients who participated in this study. This study was funded with the support of (a) an Invitation Research Grant from Faculty of Medicine, Khon Kaen University (IN62220), (b) a Research Fund from Khon Kaen University (2019), (c) Research Institute for Human High Performance and Health Promotion, Khon Kaen University (d) JSPS Core University Program. The authors would like to thank Dr.Noel Pabalan for assistance with the English proofreading of the manuscript.

\section{References}

Amadori D, Serra P, Masalu N, et al (2017). Vitamin D receptor polymorphisms or serum levels as key drivers of breast cancer development? The question of the vitamin $\mathrm{D}$ pathway. Oncotarget, 8, 13142-56.

Arjumand W, Ahmad ST, Seth A, Saini AK, Sultana S (2012). Vitamin D receptor FokI and BsmI gene polymorphism and its association with grade and stage of renal cell carcinoma in North Indian population. Tumor Biol, 33, 23-31.

Bodiwala D, Luscombe CJ, French ME, et al (2004). Polymorphisms in the Vitamin D receptor gene, ultraviolet radiation, and susceptibility to prostate cancer. Environ Mol Mutagen, 43, 121-7.

Bray F, Ferlay J, Soerjomataram I, et al (2018). Global cancer statistics 2018: GLOBOCAN estimates of incidence and mortality worldwide for 36 cancers in 185 countries. $C A$ Cancer J Clin, 68, 394-424.

Chen L, Wei J, Zhang S, Lou Z, et al (2018). Association of VDR gene TaqI polymorphism with the susceptibility to prostate cancer in Asian population evaluated by an updated systematic meta-analysis. Onco Targets Ther, 11, 3267-80.

Clendenen TV, Arslan AA, Koenig KL, et al (2008). Vitamin
D receptor polymorphisms and risk of epithelial ovarian cancer. Cancer Lett, 260, 209-15.

Deuster E, Jeschke U, Ye Y, Mahner S, Czogalla B (2017). Vitamin D and VDR in gynecological cancers-A systematic review. Int $J \mathrm{Mol} S \mathrm{Sci}, \mathbf{1 8}$, pii: E2328.

Dou R, Ng K, Giovannucci EL, Manson JE, Qian ZR, Ogino S (2016). Vitamin D and colorectal cancer: Molecular, epidemiological and clinical evidence. Br J Nutr, 115, 1643-60.

Feldman D, Krishnan AV, Swami S, Giovannucci E, Feldman BJ (2014). The role of vitamin D in reducing cancer risk and progression. Nat Rev Cancer, 14, 342-57.

Flügge J, Krusekopf S, Goldammer M, et al (2007). Vitamin D receptor haplotypes protect against development of colorectal cancer. Eur J Clin Pharmacol, 63, 997-1005.

Gapska P, Scott RJ, Serrano-Fernandez P, et al (2009). Vitamin $\mathrm{D}$ receptor variants and breast cancer risk in the Polish population. Breast Cancer Res Treat, 115, 629-33.

Guo H, Guo J, Xie W, Yuan L, Sheng X (2018). The role of vitamin D in ovarian cancer: epidemiology, molecular mechanism and prevention. J Ovarian Res, 11, 71.

Israni N, Goswami R, Kumar A, Rani R (2009). Interaction of Vitamin D receptor with HLA DRB $1 * 0301$ in Type 1 diabetes patients from North India. PLoS One, 4, e8023.

Kaabachi W, Kaabachi S, Rafrafi A, et al (2014). Association of vitamin D receptor FokI and ApaI polymorphisms with lung cancer risk in Tunisian population. Mol Biol Rep, 41, 6545-53.

Köstner K, Denzer N, Müller CSL, et al (2009). The relevance of Vitamin D Receptor (VDR) gene polymorphisms for cancer: A review of the literature. Anticancer Res, 29, 3511-36.

Li K, Luo Y, Mo Y, et al (2018). Association between vitamin D receptor gene polymorphisms and idiopathic hypocitraturia in a Chinese Bai population. Urolithiasis, 47, 235-42.

Liu Y, Li C, Chen P, et al (2013). Polymorphisms in the Vitamin $\mathrm{D}$ receptor (VDR) and the risk of ovarian cancer: A MetaAnalysis. PLoS One, 8, e66716.

McCullough ML, Stevens VL, Diver WR, et al (2007). Vitamin D pathway gene polymorphisms, diet, and risk of postmenopausal breast cancer: A nested case-control study. Breast Cancer Res, 9.

McCullough ML, Bostick RM, Mayo TL (2009). Vitamin D Gene pathway polymorphisms and risk of colorectal, breast, and prostate cancer. Annu Rev Nutr, 29, 111-32.

Natphopsuk S, Settheetham-Ishida W, Sinawat S, et al (2012). Risk factors for cervical cancer in Northeastern Thailand: Detailed Analyses of Sexual and Smoking Behavior. Asian Pac J Cancer Prev, 13, 5489-95.

Onen IH, Ekmekci A, Eroglu M, et al (2008). Association of genetic polymorphisms in Vitamin D receptor gene and susceptibility to sporadic prostate cancer. Exp Biol Med, 233, 1608-14.

Pike JW, Meyer MB (2012). The Vitamin D receptor: New paradigms for the regulation of gene expression by 1,25-Dihydroxyvitamin D3. Rheum Dis Clin North Am, 38, 13-27.

Reichrath J, Rafi L, Müller SM, etal (1998). Immunohistochemical analysis of 1,25-dihydroxyvitamin D3 receptor in cervical carcinoma. Histochem J, 30, 561-7.

Reis GVOP dos, Gontijo NA, Rodrigues KF, et al (2017). Vitamin D receptor polymorphisms and the polycystic ovary syndrome: A systematic review. J Obstet Gynaecol Res, 43, 436-46.

Samuel S, Sitrin MD (2008). Vitamin D's role in cell proliferation and differentiation. Nutr Rev, 66, 116-24.

Selvaraj P, Prabhu Anand S, Harishankar M, Alagarasu K (2009). Plasma 1,25 dihydroxy vitamin D3level and expression 
of vitamin D receptor and cathelicidin in pulmonary tuberculosis. J Clin Immunol, 29, 470-8.

Serrano D, Gnagnarella P, Raimondi S, Gandini S (2016). Meta-analysis on vitamin D receptor and cancer risk: focus on the role of TaqI, ApaI, and Cdx2 polymorphisms. Eur $J$ Cancer Prev, 25, 85-96.

Tworoger SS, Lee IM, Buring JE, et al (2007). Plasma 25-hydroxyvitamin D and 1,25-dihydroxyvitamin D and risk of incident ovarian cancer. Cancer Epidemiol Biomark Prev, 16, 783-8.

Uitterlinden AG, Fang Y, Van Meurs JBJ, Pols HAP, Van Leeuwen JPTM (2004). Genetics and biology of vitamin D receptor polymorphisms. Gene, 338, 143-56.

Vahedpoor Z, Jamilian M, Bahmani F, et al (2017). Effects of long-term Vitamin D supplementation on regression and metabolic status of cervical intraepithelial neoplasia: a Randomized, Double-Blind, Placebo-Controlled Trial. Horm Cancer, 8, 58-67.

Wang J, He Q, Shao YG, Ji M, Bao W (2013). Associations between vitamin $\mathrm{D}$ receptor polymorphisms and breast cancer risk. Tumor Biol, 34, 3823-30.

Wang K, Wu G, Li J, Song W (2016). Role of vitamin D receptor gene $\mathrm{Cdx} 2$ and Apa 1 polymorphisms in prostate cancer susceptibility: A meta-analysis. BMC Cancer, 16, 674.

Wang SS, Gonzalez P, Yu K, et al (2010). Common genetic variants and risk for HPV persistence and progression to cervical cancer. PLoS One, 5, e8667.

Whitfield GK, Remus LS, Jurutka PW, et al (2001). Functionally relevant polymorphisms in the human nuclear vitamin D receptor gene. Mol Cell Endocrinol, 177, 145-59.

\section{(c) (i) (8)}

This work is licensed under a Creative Commons AttributionNon Commercial 4.0 International License. 